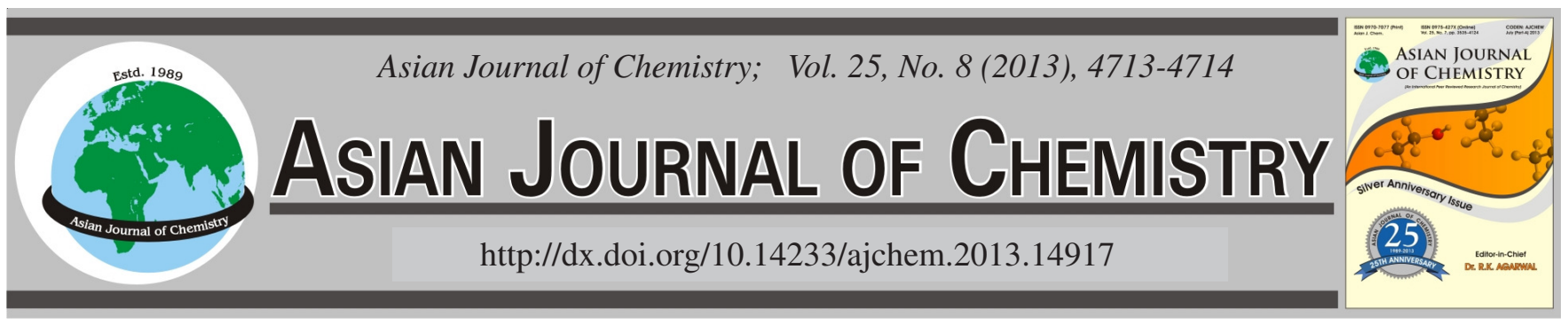

NOTE

\title{
In vitro Radioprotective Activity of the Bryozoan Hyalinella punctata
}

Boris Pejin ${ }^{1, *}$, Bojana Stanimirovic ${ }^{2}$, Neda Djordjevic ${ }^{3}$, Aleksandar Hegedis ${ }^{1}$, Ivo Karaman ${ }^{4}$, Mladen Horvatovic ${ }^{4}$ and Ksenija Radotic ${ }^{1}$

${ }^{1}$ Institute for Multidisciplinary Research, University of Belgrade, Belgrade, Serbia

${ }^{2}$ MOL d.o.o., Belgrade, Serbia

${ }^{3}$ Faculty of Chemistry, University of Belgrade, Belgrade, Serbia

${ }^{4}$ Faculty of Sciences, University of Novi Sad, Novi Sad, Serbia

*Corresponding author: E-mail: brspjn@gmail.com; borispejin@imsi.rs

(Received: 5 December 2012;

Accepted: 28 February 2013)

AJC-13054

The objective of the present study was in vitro evaluation of radioprotective activity of the freshwater bryozoan Hyalinella punctata on
cultured human peripheral blood lymphocytes after irradiation with $2 \mathrm{~Gy}$ of ${ }^{60} \mathrm{Co} \gamma$-rays. Since its water extract at concentration $0.001 \mathrm{mg} /$
$\mathrm{mL}$ reduced the incidence of radiation-induced micronuclei for almost $30 \%$, it could be considered as a promising source of new natural
products with the aforementioned activity. Both the content of sulphur $(1.17 \%)$, determined by gravimetric method and infrared absorption
frequences ( $76 \%$ similarity with those of bacitracin) of the investigated extract indicate the presence of organic sulphur compound(s)
such as cyclic peptides and polypeptides which might be responsible for the observed radioprotection.
Key Words: Plumatellidae, Extract, Lymphocytes, Ionising radiation.

Bryozoa (moss animals) are a phylum which many people, both scientist and layperson alike, have little if any familiarity, despite the fact they are widely distributed throughout the world's marine and freshwater environments ${ }^{1}$. These invertebrates are sessile, colonial, filter-feeding organisms with about 4.000 extant species most of which are marine ${ }^{2,3}$. An intricate network of metabolites is present in the extracts of bryozoans including heteroatom-containing compounds ${ }^{3}$. However, most of the studies have focused strictly on the marine species. Freshwater bryozoans live in lotic and lentic water and feed on suspended organic particles ${ }^{4}$. Hyalinella punctata is one of the bryozoans of such origin which has been noticed in Serbia $^{5,6}$.

Radiation is an important modality in the treatment of cancer and in some instances it may be the single best solution. This kind of therapy depends on achieving a therapeutic differential (with chemical radiation sensitisers or protectors) between the cancer cell cytotoxicity and normal tissue toxicity.

In recent years, extensive studies have been conducted to evaluate the potential beneficial effects of natural products in radiorecovery and the protection of normal tissue during exposure to radiation ${ }^{7}$. Historically, sulfhydryl compounds were among the first radioprotectors to be identified ${ }^{8}$. In the course of our ongoing experiments on invertebrates ${ }^{9-11}$, in vitro radioprotective activity of the bryozoan $H$. punctata was investigated for the first time.

The sample of Hyalinella punctata (Hancock, 1850) was collected in Belgrade (river Danube, Serbia, November 2011). Voucher specimen has been deposited in the Zoology Collection of the Department of Biology and Ecology of the University of Novi Sad, Serbia (BRY 003).

After carefully cleaning from contaminants, the bryozoan sample was lyophilised. The dried parts of $H$. punctata were ground ( $2 \mathrm{~g}$ ) and extracted thrice with hot water for $1 \mathrm{~h}$ at room temperature. The extract was evaporated to dryness and stored at $-20^{\circ} \mathrm{C}$ until further use.

Fourier-transform infrared (FTIR) spectrum of the investigated extract was recorded in the attenuated total reflection mode (ATR) using a Nicolet 6700 FTIR Spectrometer (Thermo Scientific).

Blood samples were obtained from three healthy, nonsmoking young male volunteer donors at the Medical Unit in accordance with current health and ethical regulations in Serbia $^{12}$. Heparinised whole blood was aliquoted into sterile plastic test tubes, placed in a $15 \mathrm{~cm} \times 15 \mathrm{~cm}$ Plexiglas container and irradiated using a ${ }^{60} \mathrm{Co} \gamma$-ray source at room temperature. The radiation dose employed was $2 \mathrm{~Gy}$, the dose rate was 0.45 $\mathrm{Gy} / \mathrm{min}$, the dimensions of the radiation field were $20 \mathrm{~cm} \times$ 
$20 \mathrm{~cm}$ and the distance from the radiation was $74 \mathrm{~cm}$. After $1 \mathrm{~h}$ irradiation, $0.5 \mathrm{~mL}$ aliquots of whole blood were added to culture tubes containing $4.5 \mathrm{~mL}$ of PBmax karyotyping medium (Invitrogen-Gibco, Paisley, UK). Irradiated and positive control cultures were established. The optimum dose for evaluation of radioprotection was selected based on previously conducted experiments employing different concentrations of the bryozoan extract for the treatment of irradiated human lymphocytes.

For micronuclei preparation, the cytokinesis block method of Fenech et al. ${ }^{13}$ was used. For each sample, at least 1000 binucleate cells were scored and micronuclei were recorded using an AxioImager A1 microscope (Carl Zeiss, Jena, Germany) with $400 \times$ or $1000 \times$ magnification. The ability of cells to proliferate in vitro was evaluated by counting the number of cells with one to four micronuclei on the same slides $^{14}$.

Statistical analysis was performed using the statistical software package Statistica 6.0 for Microsoft Windows. Statistical analysis was done using Student's t-test and a P value $<0.05$ was considered to be significant.

The water extract of $H$. punctata has reduced the incidence of radiation-induced micronuclei $(\mathrm{MN})$; a reduction of $28.17 \%$ compared to control cells (Table-1). Both the content of sulphur $(1.17 \%)$, determined by gravimetric method ${ }^{15}$ and infrared absorption frequences $(76 \%$ similarity with those of bacitracin; not shown here) of the investigated extract indicate the presence of organic sulphur compound(s) such as cyclic peptides and polypeptides which might be responsible for the observed biological activity ${ }^{16}$.

TABLE-1

INCIDENCE OF MICRONUCLEI (MN) IN EXAMINED SAMPLES

\begin{tabular}{ccc}
\hline $\begin{array}{c}\text { Basal value } \\
\text { of MN/1000 } \\
\text { BN cells }\end{array}$ & $\begin{array}{c}\text { Incidence of MN/1000 } \\
\text { BN cells irradiated with } \\
2 \text { Gy (control) }\end{array}$ & $\begin{array}{c}\text { Incidence of MN/1000 } \\
\text { BN cells irradiated and } \\
\text { treated with extract }\end{array}$ \\
\hline $7 \pm 2$ & $323 \pm 21$ & $232 \pm 18$ \\
\hline
\end{tabular}

The development of radiation protectors is important not only for enhancing the effectiveness of cancer treatment but also for the studying of the underlying mechanisms of the relevant cytotoxicity ${ }^{17,18}$. Indeed, some radioprotectors are known for a direct effect on the cellular targets of radiation, while others act through enhancing the recovery of normal tissues ${ }^{19}$.

Present results suggest that $H$. punctata water extract appears to confer protection against ionising radiation. More- over, it is the first record ever of radioprotectivity of the bryozoan species as a whole. Therefore, the potential use of $H$. punctata-derived natural products in the radiation therapy is worthy for further investigation.

\section{ACKNOWLEDGEMENTS}

This work was financially supported by the Ministry of Education, Science and Technological Development of the Republic of Serbia (\# III45012, 172053, 173040 and III43007). The authors are grateful for the technical assistance from Vinca Institute of Nuclear Sciences in Belgrade (\# 173046).

\section{REFERENCES}

1. C. Christophersen, in ed.: A. Brossi, Marine Alkaloids, The Alkaloids: Chemistry and Pharmacology, Academic Press, New York, pp. 25-112 (1985).

2. J.S. Ryland, Bryozoans, Hutchinson University Library, London, pp. 175 (1970)

3. X.-R. Tian, H.-F. Tang, Y.-S. Li, H.-W. Lin, X.-L. Chen, N. Ma, M.-N. Yao and P.-H. Zhang, Mar. Drugs, 9, 162 (2011).

4. T.S. Wood, in eds.: J. Thorp and A. Corvich, Bryozoans, Ecology and Classification of North American Freshwater Invertebrates, Academic Press, New York, pp. 505-525 (2001).

5. G. Markovic, T. Karan-•nidaršic and P. Simonovic, Polish J. Ecol., 57, 201 (2009).

6. V.M. Martinovic-Vitanovic, V.M. Milankov and V.I. Kalafatic, Limnologica, 40, 73 (2010).

7. S. Petrovic, A. Leskovac and G. Joksic, Curr. Sci. (India), 95, 1035 (2008).

8. H.M. Patt, E.B. Tyree, R.L. Straube and D.E. Smith, Science, 110, 213 (1949).

9. B. Pejin, C. Iodice, G. Tommonaro and S. De Rosa, J. Nat. Prod., 71, 1850 (2008).

10. S. De Rosa, B. Pejin and G. Tommonaro, 4th International Conference on Oxidative Stress in Skin Medicine and Biology, Book of Abstracts, pp. 53 (2008).

11. B. Pejin, J. Glamoclija, A. Ciric, K Radotic, V. Vajs, V. Tesevic, A. Hegedis, I. Karaman, M. Horvatovic and M. Sokovic, Dig. J. Nanomater. Biostruct., 7, 1021 (2012).

12. Law on Health Care, Official Gazette of the Republic of Serbia, Parliament of the Republic of Serbia, pp. 107, 112 (2005).

13. M. Fenech, Mutat. Res., 285, 35 (1993).

14. J. Surrales, N. Xamena, A. Creus and R. Marco, Mutat. Res., 342, 43 (1995).

15. W. Rieman III and G. Hagen, Ind. Eng. Chem. Anal. Ed., 14, 150 (1942).

16. K. Dittman, M. Toulany, J. Classen, V. Heinrich, L. Milas and H.P. Rodermann, Strahlenther. Onkol., 181, 191 (2005).

17. J. Dunst, S. Semli, S. Pigorsch, A.C. Muller and T. Reese, Strahlenther. Onkol., 176, 416 (2000).

18. A. Vacek, V. Tacev and M. Hoffer, Strahlenther. Onkol., 177, 474 (2001).

19. S.M. Hahn, M.C. Krishna, A. Samuni, W. DeGraff, D.O. Cuscela, P. Johnstone and J.B. Mitchell, Cancer Res., 54, 2006S (1994). 